ISSN 0258-7122

Bangladesh J. Agril. Res. 40(1): 53-60, March 2015

\title{
EFFECT OF NITROGEN LEVEL AND LEAF CUTTING FREQUENCY ON FOLIAGE AND SEED YIELDS OF CORIANDER
}

\author{
M. MONIRUZZAMAN ${ }^{1}$ AND M. M. RAHMAN ${ }^{2}$
}

\begin{abstract}
A field experiment was conducted at BSMRAU farm, Gazipur to evaluate the effects of four nitrogen levels $(0,40,80$ and $120 \mathrm{~kg} / \mathrm{ha})$ and four levels of leaf cutting ( no cutting, one cutting at 30 DAS), two cuttings at $30 \& 45$ DAS and three cuttings at $30,45 \& 60$ DAS ) on three genotypes of coriander (Coriandrum sativum L.) (CS001, CS002 and CS003). The genotype CS003 produced the highest foliage yield (8.92 t/ha) and the genotype CS001 gave the highest seed yield $(0.93 \mathrm{t} / \mathrm{ha})$. The maximum foliage and seed yields were obtained from the $\mathrm{N}$ application at $80 \mathrm{~kg} \mathrm{~N} / \mathrm{ha}$. The maximum foliage yield (11.21 t/ha) was recorded with the three cuttings, but the highest seed yield was noted with the one cutting (1.06 t/ha). The $80 \mathrm{~kg} \mathrm{~N} / \mathrm{ha}$ coupled with three cuttings gave the top most foliage yield while the same rate accompanied with one cutting gave the top most seed yield for all genotypes.
\end{abstract}

Keywords: Nitrogen, leaf cutting, green leaf, seed yield, coriander, Coriandrum sativum $\mathrm{L}$.

\section{Introduction}

Coriander (Coriandrum sativum L.) in Bangladesh is an important spice crop grown in rabi season and it is known as 'dhonia'. The young plant of coriander is used as appetizer in preparing fresh chutneys and sauces and leaves are used to flavour food, curries, soups, fish sauce, etc. and seeds are used in cakes, soups, sausage, pickles, curries, etc. (Janardhanan and Thoppil, 2004; Tiwary and Agarwal, 2004). Coriander seeds are also used in preparation of medicines (Sharma and Sharma, 2004). Two types of genotypes are available in respect of seed and foliage production purposes. Some genotypes are exclusively cultivated for seed purposes and some are cultivated for seed as well as foliage (leaf) production. The later is called dual purpose genotype. In Bangladesh, seed purpose varieties as well as dual purpose varieties are imported from foreign countries.

Leaf cutting and nitrogen application have been reported to increase the number of branches and umbels per plant which in turn increased the yield of leaves and seeds in coriander (Thakral et al. 1992; Tiwari et al., 2002). Application of nitrogen encourages vegetative growth which resulted in the increased yield of

${ }^{1}$ Senior Scientific Officer, HRC, Bangladesh Agricultural Research Institute (BARI), ${ }^{2}$ Professor, Dept. of Horticulture, Bangabandhu Shekh Mujibur Rahman Agricultural Univeristy (BSMRAU), Salna, Gazipur-1706, Bangladesh 
leaves and seeds of coriander (Datta et al. (2008). The present study was undertaken to find out the optimum dose of nitrogen for higher leaf and seed yield and to determine the frequency of leaf cutting in relation to leaf and seed yield of coriander.

\section{Materials and Method}

The experiment was conducted at the research farm of Bangabandhu Sheikh Mujibur Rahman Agricultural University (BSMRAU), Gazipur (AEZ-28) during November 2009 to May 2010. The experimental field comprised with the Piedmont plain soil having medium loamy to moderately fine texture (sandy clay loam). The soil was poor in organic matter (1.91\%) and moderately acidic ( $\mathrm{pH}$ 5.90). The total $\mathrm{N}$, available $\mathrm{P}$, exchangeable $\mathrm{K}$, available $\mathrm{S}$ and $\mathrm{B}$ in soil were $0.079 \%, 30.77 \mathrm{ppm}, 0.35 \mathrm{meq} / 100 \mathrm{~g}$ soil, $13.4 \mathrm{ppm}$ and $0.31 \mathrm{ppm}$, respectively.

The experiment was laid out in a split-split plot design with three replications having three genotypes (CS001, CS002 and CS003) in main plots, four nitrogen levels ( 0, 40, 80 and $120 \mathrm{~kg} / \mathrm{ha}$ ) in sub-plots and four levels of leaf cutting (No cutting, one cutting at 30 DAS, two cuttings at 30 and 45 DAS and three cuttings at 30, 45 and 60 DAS) in sub-sub plots. The coriander genotypes were collected from Siddique Bazzar, Dhaka. The unit plot size was $3 \times 1 \mathrm{~m}$. The first and the second leaf cutting were done $4 \mathrm{~cm}$ above the ground leaving the terminal bud during the third cutting the suitable leaves are cut.

The land was fertilized @ $5 \mathrm{t}$ cowdung, $40 \mathrm{~kg} \mathrm{P}, 40 \mathrm{~kg} \mathrm{~K}$ and $20 \mathrm{~kg} \mathrm{~S}$ per hectare. Full amount of cowdung, TSP, MOP and gypsum was added as basal application. One- half of urea was applied during final land preparation and the rest of the urea was applied in three equal instalments after each cutting as top dress. The seeds (fruits) were rubbed for separating the two mericarps (seeds) and were soaked in water for 24 hours to enhance germination. Seed were also treated with Bavistin at $2 \mathrm{~g}$ per $\mathrm{kg}$ of seeds before sowing. The seeds were sown in $20 \mathrm{~cm}$ apart lines continuously by hand @ $30 \mathrm{~kg} / \mathrm{ha}$. Sowing was done on November 9, 2009. First and second weedings were done after 25 and 60 days after sowing, respectively. Plant thinning was done at 25 DAS maintaining $10 \mathrm{~cm}$ distance between plants. Irrigation was done at 30, 45, 60 and 85 days after sowing. Malathion@ $1.5 \mathrm{ml} / \mathrm{l}$ was sprayed during fruiting stage to reduce the attack of aphid.

Harvesting of leaves was done at 30, 45 and 60 days after sowing. Seeds were harvested when half of the fruits on the plant changed from green to brown colour (Singhania et al. 2006). Seeds were dried in the sun to attain $10 \%$ moisture.

Data were recorded umbels/plant, umbelletes/plant, seeds/umbel, 1000-seed weight (g), stover yield and seed yield (t/ha). Plot yield was converted to per 
hectare yield. The data were analyzed statistically by MSTAT-C Program and mean comparison was done following the Duncan Multiple Range Test (DMRT).

\section{Results and Discussion}

Data on effects of genotypes, $\mathrm{N}$ levels and leaf cutting frequency have been shown in Tables 1-5.

Effect of genotypes: Umbels/plant (33.1), umbellates/umbel (5.47) and seeds/umbel (20.52) were found highest with CS001 followed by CS002 and then CS003 (Table 1). The CS002 gave the maximum 1000-seed weight (11.7 g) compared to other genotypes. The genotypes CS001 and CS003 gave the identical result in respect of 1000 -seed weight. The genotype CS003 produced the highest foliage yield $(8.92 \mathrm{t} / \mathrm{ha})$ and the CS001 did the lowest $(6.95 \mathrm{t} / \mathrm{ha})$. The highest seed yield was recorded from CS001 (0.93 t/ha) followed by CS002 (0.89 $\mathrm{t} / \mathrm{ha}$ ) and then CS003 (0.79 t/ha). The genotype CS003 produced the higher stover yield (1.95 t/ha) and the CS001 and CS002 gave an identical yield (1.36 t/ha).

Effect of nitrogen level: Application of $80 \mathrm{~kg}$ N/ha produced the highest umbellates/umbel (5.75) followed by $120 \mathrm{~kg} \mathrm{~N} / \mathrm{ha}$ (Table 1). The maximum seeds/umbel was recorded at both 80 and $120 \mathrm{~kg} \mathrm{~N} / \mathrm{ha} \mathrm{(21.3)} \mathrm{followed} \mathrm{by} 40 \mathrm{~kg}$ $\mathrm{N} / \mathrm{ha}$ (20.3). The highest 1000-seed weight was obtained from the application of $80 \mathrm{~kg} \mathrm{~N} / \mathrm{ha}$. The yield of foliage increased progressively with the increase of $\mathrm{N}$ levels up to $80 \mathrm{~kg} \mathrm{~N} / \mathrm{ha}$ beyond which it declined (Table 1). Similar trend was observed with $\mathrm{N}$ application at $80 \mathrm{~kg} \mathrm{~N} / \mathrm{ha}(1.11 \mathrm{t} / \mathrm{ha})$. Higher rate of $\mathrm{N}$ application $(120 \mathrm{~kg} / \mathrm{ha})$ was not beneficial in respect of seed yield as it produced more vegetative growth and less reproductive growth. Thakral et al. (1992) reported the highest number of umbels/plant and seed yield $(15.98 \mathrm{q} / \mathrm{ha})$ at $60 \mathrm{~kg}$ $\mathrm{N} / \mathrm{ha}$ and the highest green leaf yield at $90 \mathrm{~kg} \mathrm{~N} / \mathrm{ha}$. Datta et al. (2006) observed that number of umbels/plant, number of seeds/umbel green leaf yield and seed yield increased significantly up to $60 \mathrm{~kg} \mathrm{~N} / \mathrm{ha}$. The stover yield due to 80 and $120 \mathrm{~kg} \mathrm{~N} / \mathrm{ha}$ was statistically similar (Table 1).The $\mathrm{N}$ control treatment for all parameters showed the lowest results.

Effect of leaf cutting frequency: Umbels/plant (36.5), umbellates/umbel (5.70) and seeds/umbel (24.3) were recorded as the highest from one cutting $\left(\mathrm{C}_{1}\right)$ followed by no cutting $\left(\mathrm{C}_{0}\right)$ and their lowest values were obtained from three cuttings $\left(\mathrm{C}_{3}\right)$. The 1000 -seed weight was not influenced by cutting frequency. The yield of foliage increased with the increasing frequency of cuttings (Table 1). The significantly maximum foliage yield $(11.21 \mathrm{t} / \mathrm{ha})$ was obtained from three cuttings $\left(\mathrm{C}_{3}\right)$ and the minimum $(9.24 \mathrm{t} / \mathrm{ha})$ from one cutting $\left(\mathrm{C}_{1}\right)$. This result is in agreement with Thakral et al. (1992) and Datta et al. (2008) in coriander. The maximum seed yield was obtained from one cutting $\left(\mathrm{C}_{1}\right)(1.06 \mathrm{t} / \mathrm{ha})$ followed by 


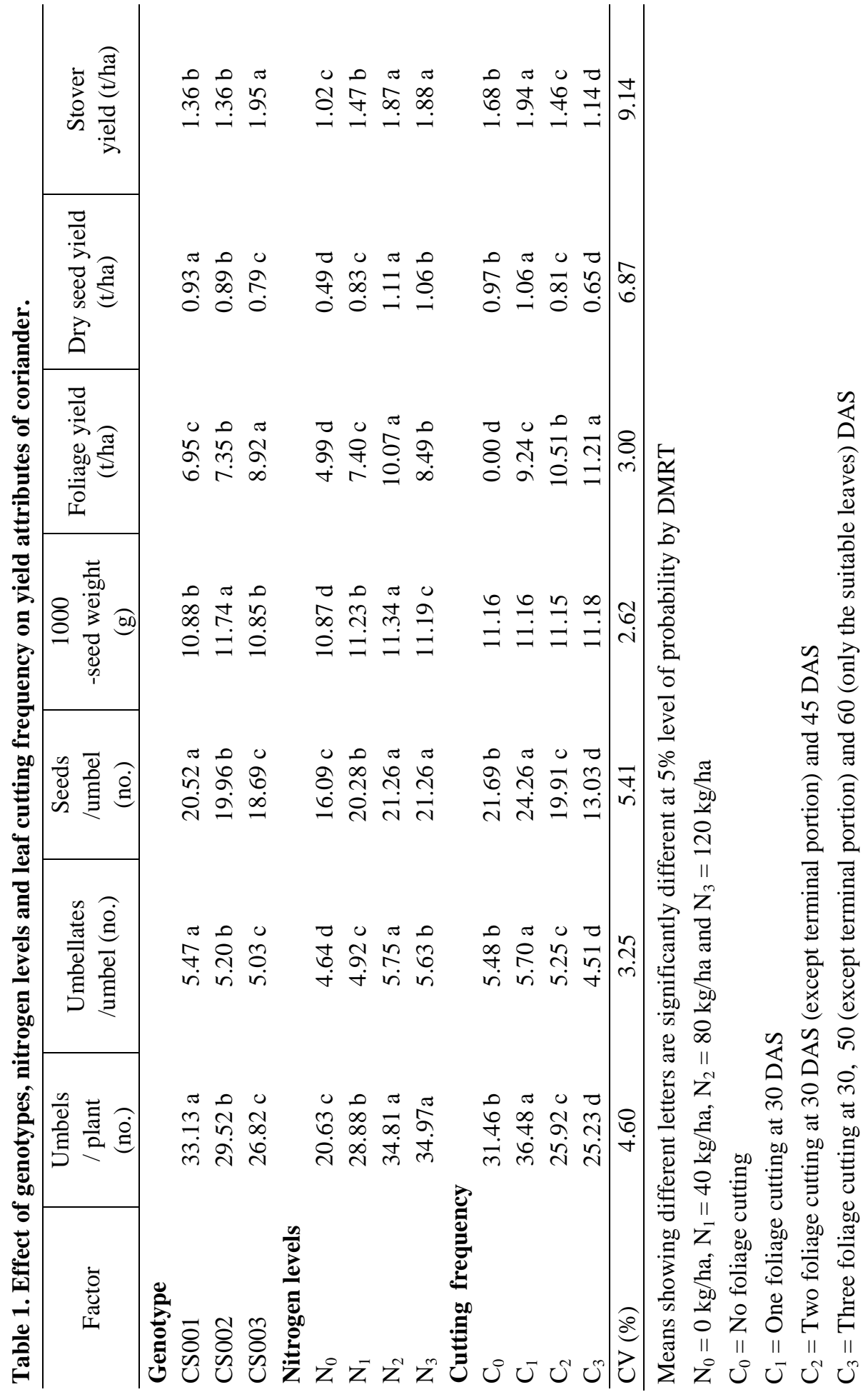




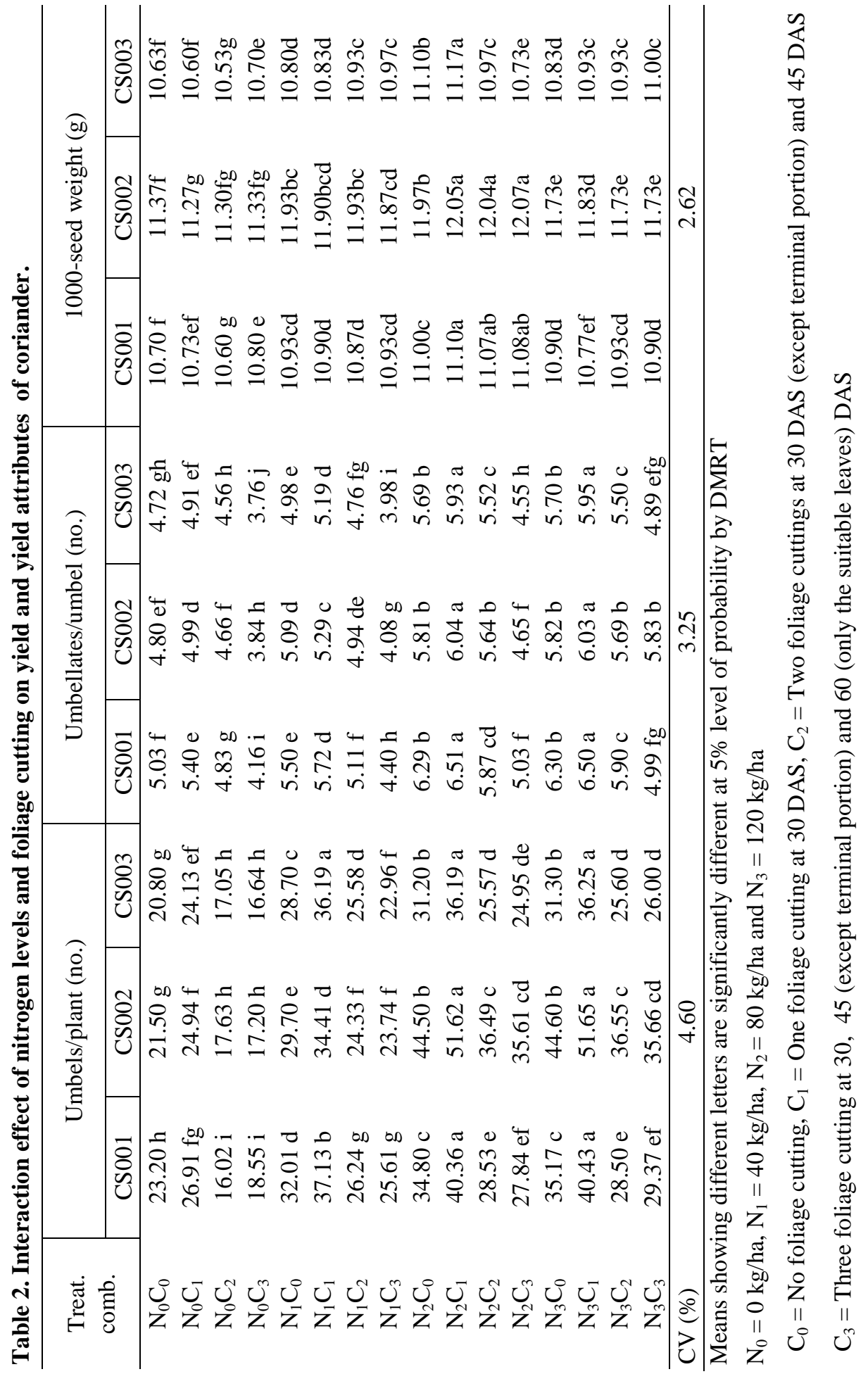




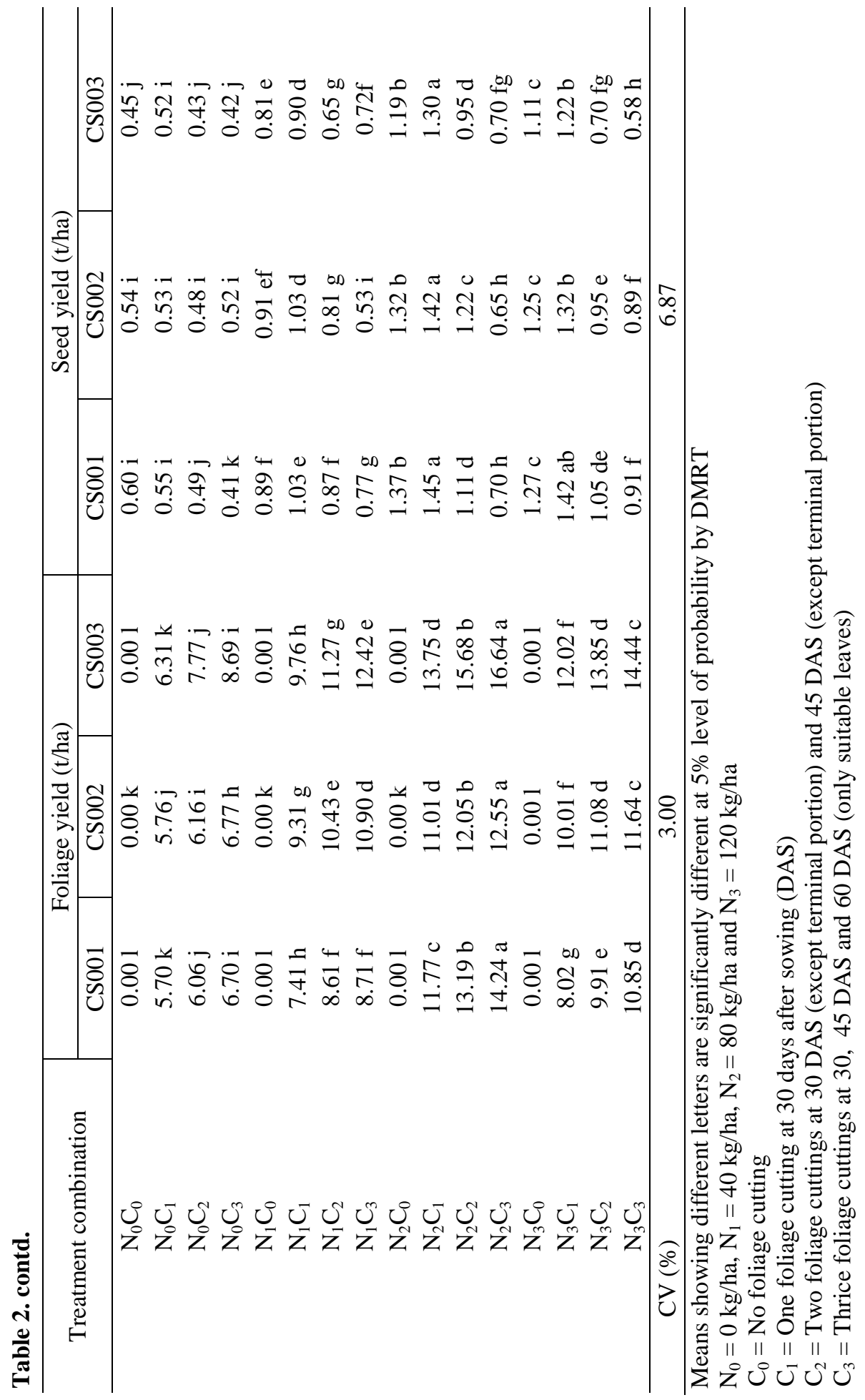


no cutting $(0.97 \mathrm{t} / \mathrm{ha})$ and the lowest seed yield was recorded from three cuttings at 30,45 and 60 DAS $\left(\mathrm{C}_{3}\right)$. The single cutting (30 DAS) did not affect the vegetative and reproductive growth that resulted in the highest seed yield. The plants of no cutting had a lot of leaves at the basal portion of the stems; these older leaves actually acted as sink that reduced the seed yield. This finding also corroborates with the findings of Thakral et al. (1992). On the contrary, Datta et al. (2008) obtained significantly higher seed yield from no cutting compared to one cutting. Tiwari et al. (2002) observed the highest number umbels per plant and the highest seed yield with two leaf cuttings. Rema et al. (1997) reported that once leaf plucking at 50 DAS did not significantly reduce seed yield compared to the control treatment. In case of stover yield similar trend was also observed with cuttings where one cutting $\left(\mathrm{C}_{1}\right)$ produced the maximum stover yield $(1.94 \mathrm{t} / \mathrm{ha})$ significantly compared to other cuttings.

Interaction effect of nitrogen levels and foliage cutting: For all genotypes, the maximum umbels/plant was recorded from $\mathrm{N}_{3} \mathrm{C}_{1}$ closely followed by $\mathrm{N}_{2} \mathrm{C}_{1}$ and $\mathrm{N}_{1} \mathrm{C}_{1}$ in CS003. The second highest umbels/plant was obtained from $\mathrm{N}_{3} \mathrm{C}_{0}$ closely followed by $\mathrm{N}_{2} \mathrm{C}_{0}$. The maximum number of umbellates/umbel was obtained from $\mathrm{N}_{2} \mathrm{C}_{1}$ closely followed by $\mathrm{N}_{3} \mathrm{C}_{1}$ in each genotype. The $\mathrm{N}_{3} \mathrm{C}_{1}$ and $\mathrm{N}_{2} \mathrm{C}_{1}$ gave the identical second maximum umbellates/umbel. The maximum 1000-seed weight was obtained from $\mathrm{N}_{2} \mathrm{C}_{1}$ closely followed by $\mathrm{N}_{2} \mathrm{C}_{2}$ and $\mathrm{N}_{2} \mathrm{C}_{3}$ in CSO01 and CS002 except CS003. The $\mathrm{N}_{3}$ treatment failed to give the maximum 1000-seed weight irrespective of cutting treatments in all genotypes. The maximum foliage yield was obtained from $\mathrm{N}_{2} \mathrm{C}_{3}$ in CS001 (14.2 t/ha), CS002 (12.6 t/ha) and CS003 (16.6 t/ha). The $\mathrm{N}_{3} \mathrm{C}_{3}$ was unable to give the highest foliage yield probably due to non utilization of the whole nitrogen. The second highest foliage yield was recorded from $\mathrm{N}_{2} \mathrm{C}_{2}$ in all genotypes followed by $\mathrm{N}_{3} \mathrm{C}_{3}$ in CSO02 and CSO3 and by $\mathrm{N}_{2} \mathrm{C}_{1}$ in CS001. The result was in close conformity with Thakral et al. (1992). But the result differed from Datta et al. (2008) who obtained the maximum leaf yield from the interaction of $90 \mathrm{~kg} \mathrm{~N} / \mathrm{ha}$ and two leaf cuttings. The combination $\mathrm{N}_{2} \mathrm{C}_{1}$ produced the maximum seed yield in all genotypes, highest in CS001. In CS001, $\mathrm{N}_{2} \mathrm{C}_{1}$ and $\mathrm{N}_{3} \mathrm{C}_{1}$ gave the identical seed yield. The second highest seed yield was recorded from $\mathrm{N}_{2} \mathrm{C}_{1}$. The lowest yield was noticed in $\mathrm{N}_{0} \mathrm{C}_{3}$. Although the combinations of $\mathrm{N}_{3} \mathrm{C}_{1}$ and $\mathrm{N}_{2} \mathrm{C}_{1}$ showed identical results with regard umbels/plant and umbellates/umbel, $\mathrm{N}_{3} \mathrm{C}_{1}$ failed to give the maximum 1000-seed weight compared to $\mathrm{N}_{2} \mathrm{C}_{1}$. For this reason the $\mathrm{N}_{3} \mathrm{C}_{1}$ combination gave lower yield (1.32 t/ha. Thakral et al. (1992) reported that significantly the highest yield of seeds was obtained from the application $60 \mathrm{~kg} \mathrm{~N} / \mathrm{ha}$ with one leaf cutting in coriander.

From the investigation, it appears that the response of coriander crop to nitrogen levels and leaf cuttings was fairly well in terms of the production of foliage (green leaves) as well as seed in Salna areas (AEZ-28). It was evident that the 
application of $80 \mathrm{~kg} \mathrm{~N} / \mathrm{ha}$ with two cuttings of foliage at 30 and 45 DAS was the most suitable for coriander cultivation. Application of $80 \mathrm{~kg} \mathrm{~N} / \mathrm{ha}$ with one cutting of foliage at 30 DAS might also be advocated for coriander production for foliage as well as seed.

\section{References}

Datta, S and P. Choudhuri. 2006. Evaluation of coriander germplasm under tetra zone of West Bengal. Haryan J. Hortic. Sci. 35(3 \& 4): 348-349.

Datta, S., K. Alam and R. Chatterjee. 2008. Effect of different levels of nitrogen and leaf cutting on growth, leaf and seed yield of coriander. Indian J. Hort. 65(2): 201-203.

Janardhan, M. and J. E. Thoppil. 2004. Herb and Spice Essential Oils. Discovery Publishing House, New Delhi-110002. Pp. 40-42.

Rema, M. M. A. Khader and R. Menon. 1997. Effect of leaf plucking on the growth and grain yield of coriander. Indian Cocoa, Arecanut Spices J. 21 (3): 74-75.

Sharma, M. M and R. K. Sharma. 2004. Coriander. In Handbook of herbs and spices. Vol. 2 (ed.) Peter k. V. Woodhead Pub. Abington Hall, Abington Cambridge CBI 6AH, England. Pp.145-161.

Singhania, D.L., D. Singh and R. S. Raje. 2006. Coriander. In: Ravindran, P. R., K. N. Babu, K. N. Shiva. and J. A. Kallupurackal (eds.). Advances in Spices and Achievments of Spices Research in India since Independence. pp. 678-695. Agrobios (India), Agro House, Behind Nasrani Cinema. Chopasani Road. Jodhpur 342002.

Thakral, K. K., G. R. Singh, U. C. Pandey and V. K. Srivastava. 1992. Effect of nitrogen levels and cuttings on the production of green leaves and seed yield of coriander cv. Narnaul Selection. Haryana Agril. Univ. J. Res. 22 (1): 35-39.

Tiwari, R. S. and A. Agrawal. 2004. Production Technology of Spices. $1^{\text {st }}$ ed. International Book Distribution Co. Chaman Studio Building, $2^{\text {nd }}$ floor, Charbagh, Lucknow, 2260004 U. P., India. Pp. 254-271.

Tiwari, R. S., Ankur Agarwal, S. C. Sengar and A. Agarwal. 2002. Effect of dates of sowing and number of cuttings on growth, seed yield and economics of coriander cv. Pant Haritima. Crop Res. Hisar. 23 (2): 324-329. 